\title{
De ruas estreitas e outros espaços: as domésticas de Recife e Salvador $(1870-1910)^{*}$
}

Maciel Henrique Silva

Resumo: O artigo discute as experiências de trabalhadoras domésticas de Recife e Salvador em torno de 1900. Entendo tais experiências a partir da relação campo/cidade e do processo de construção de redes sociais em contextos espaciais novos. Muitas dessas trabalhadoras eram procedentes de outras regiões e compunham o diversificado e complexo mundo do trabalho com outras categorias profissionais. Por fim, apresento conflitos e solidariedades possíveis em becos, ruas estreitas, e o significado de tais situações em um processo inacabado de formação de classe.

Palavras-Chave: Classe - Trabalhadoras domésticas - Redes sociais e espaciais

\begin{abstract}
The article discusses the experiences of domestic workers in Recife and Salvador around 1900. I understand such experiences from the rural/urban relation and from the process of building social networks in new spatial contexts. Many of these workers were from other regions and made up the diverse and complex work world with other professional groups. Finally, I present possible conflicts and solidarities in alleys and narrow streets, and the meaning of such situations in an unfinished process of class formation.
\end{abstract}

Keywords: Class - Domestic Workers - Social and spatial networks

No começo do século XX, Guiomar aportou no Recife para trabalhar como criada. Seu patrão, um senhor de engenho, conduziu-a consigo do Cabo de Santo Agostinho, tradicional região do sul de Pernambuco, produtora de açúcar, para a capital pernambucana. Claro que Guiomar não pediu isso. Ela era, provavelmente, uma daquelas descendentes de escravas do meio rural, já menos retinta na cor, mas não menos explorada no trabalho. No Recife, Guiomar vivia desconfiada, pouco falava. Sorria tímida diante do entregador de pão, em um namoro completamente platônico. Ao conversar com o namorado pelo muro, logo ouvia o grito da patroa: "Entra, Guiomar!". Sem permissão para sair de casa, o Recife lhe era um mundo estranho, fronteira indevassada, espaço incógnito, um não-lugar. Só o namoro com o entregador de pão, ainda que contido, abria-lhe uma fresta de esperança para que a cidade pudesse ser um mundo confiável, conhecido, territorializado. Mas o coronel, seu patrão,

\footnotetext{
* Este artigo resulta de uma pesquisa financiada pelo programa de bolsas PIQDTec/CAPES.

** Professor do Instituto Federal de Educação, Ciência e Tecnologia de Pernambuco - IFPE; doutorando em História pelo Programa de Pós-Graduação em História da Universidade Federal da Bahia.
} 
retornou para o engenho. Ela, então, "toda bisonha, para um canto", triste mesmo, tomou veneno e se suicidou ${ }^{1}$.

Essa historieta tem tudo para ser uma crônica de jornal, um drama real. E não deixa de ser. Contudo, ela é fruto da ficção de José Lins do Rego. O entregador de pão, também ele vindo de um engenho de Pernambuco, era Ricardo, ou melhor, O Moleque Ricardo, outro personagem que também, como Guiomar, não era lá muito adaptado ao mundo urbano, às regras desse universo novo, cheio de conflitos. Agora Ricardo buscou o Recife por decisão própria, abandonando (para depois se arrepender) a vida no engenho. Mas esse artigo não é sobre o romance mais marcadamente histórico do escritor paraibano. Apenas registro que, de sua obra, este é o romance mais voltado para o tema do trabalho, dos conflitos de operários nos primeiros decênios da República.

Para os propósitos deste texto, contudo, O Moleque Ricardo permite, ao historiador social do trabalho, refletir sobre a complexa relação entre espaços (campo/cidade) e valores (moderno/arcaico), e como espaços e valores se relacionam à dinâmica de formação de classe. Meu objetivo é, em linhas amplas, partir de José Lins do Rego para, por um lado, reconstruir cotidianos e experiências de domésticas que trabalharam no Recife e na Salvador dos anos finais do século XIX aos iniciais do XX; por outro, refletir como as experiências, as redes sociais modelavam identidades populares e de classe nas duas cidades e seus territórios.

Retorno ao romance de Rego. Ricardo, representado como o ingênuo trabalhador rural ainda pouco conhecedor do urbano, ficou chocado com as criadas da cidade, estas recifenses mesmo, respondendo a suas patroas com uma altivez nunca vista no meio rural de Pernambuco. Do mesmo modo, muitas outras criadas (não Guiomar, ainda muito tímida) saíam à rua "com seus namorados", o que, visto de uma perspectiva mais ampla, era um direito conquistado, e mesmo Ricardo, ainda matuto, fora ensinado nos mistérios do sexo pela mulata Isaura, doméstica, mas que era "negra falante", que "Falava como as brancas do Santa Rosa [engenho], usava sapatos de salto alto, lia o jornal" ${ }^{2}$. Rego diz, com isso, que é na cidade onde se constrói o sentido da classe e da luta de classes, o lugar do conflito, da demolição de valores patriarcais de ordem e obediência (e de "proteção"). Conflito que atinge mesmo as trabalhadoras domésticas, não obstante a inexistência de canais institucionais próprios, como sindicatos, associações etc. Em suma, há em Rego uma tese pronta segundo a qual submissão e obediência são a marca do trabalhador dos canaviais e

${ }^{1}$ REGO, José Lins do. O Moleque Ricardo. 16ạ ed. Rio de Janeiro: Livraria José Olympio Editora, s/d, p. 19-27. Para a noção de lugar como categoria espacial que demanda a construção de significados e a atribuição de um valor, o que implica em práticas de lazer, habitar, amar, trabalhar etc., ver CABRAL, Luiz Otávio. "Revisitando as noções de espaço, lugar, paisagem e território, sob uma perspectiva geográfica”, pp. 141-155. In Revista de Ciências Humanas, v. 41, n 1 e 2, Florianópolis, EDUFSC, Abril e Outubro de 2007.

${ }^{2}$ REGO, José Lins do. O Moleque Ricardo, p. 13, 27, 49, e sobre a criada namoradeira, Isaura, ver p. 64 e 66. 
das casas-grandes, e a rebeldia, a luta por direitos, é marca do trabalhador da cidade ${ }^{3}$. Argumento que Rego não está sozinho nessa construção romântica do trabalhador rural, e da percepção dos riscos do trabalhador urbano. Mário Sette, outro escritor (este, recifense convicto, bairrista mesmo), em 1921, também esposava o temor com a criadagem urbana, faladeira... As amas de leite do Recife, por exemplo, não eram tidas por confiáveis no romance Senhora de Engenho: melhor se arranjar com a esposa de um vaqueiro mesmo... ${ }^{4}$ Além disso, as criadas da cidade falavam entre si de patrões maus pagadores, caloteiros que só tinham a aparência de nobres e ricos ${ }^{5}$. A fofoca, no meio urbano, como forma de solidariedade e resistência.

Às imagens, muitas vezes fortes, da literatura, quero acrescentar outras imagens também intensas, compostas a partir de experiências de crianças, adolescentes e jovens mulheres que, por caminhos diversos, tiveram Salvador e Recife como seus destinos. Dor, solidariedades de classe, gênero e raça, disputas entre domésticas e amásios, nos becos estreitos, nas casas de patrões, preencherão as páginas seguintes; ao final, tento entender como as redes sociais se processam e reflito sobre como elas interferem no processo de formação de classe das trabalhadoras domésticas ${ }^{6}$.

\section{MARIA DE JESUS E A CRIADA PARAIBANA}

Em 1900, Maria de Jesus, órfã de pai, de apenas sete ou oito anos de idade - embora o Comissário que investigou o caso sempre lhe atribua seis anos -, foi envolvida em uma situação extrema que chocou o Promotor Público da capital baiana. Em Vitória da Conquista, sua mãe, que imigrara para lá "foragida da seca" que assolava o centro do Estado, entregoua para o praça do corpo de brigada da polícia da Bahia, José Pereira Pinto, "a qual tomou para educar, ou antes, a seu serviço e de sua amásia, Felicíssima Roza dos Santos" ${ }^{7}$. A autoridade judicial não sabia onde estava a mãe de Maria. O Promotor denunciou que ela era constantemente maltratada e "barbaramente espancada pelo seu pseudoptotetor e pela amásia". Maria de Jesus, segundo suas respostas ao Comissário de Polícia, já sofria maustratos desde o tempo em que vivera na "Cidade da Victoria" (Vitória da Conquista), durante

\footnotetext{
${ }^{3}$ Para uma crítica contundente da dicotomia urbano/rural e de outras dicotomias nos estudos sobre os mundos do trabalho, ver GINO, Antonio Luigi; GOMES, Flávio. "Além de senzalas e fábricas: uma história social do trabalho", p. 217-240. In Tempo Social, revista de Sociologia da USP, v. 18, n. 1, junho de 2006, p. 218.

${ }^{4}$ SETTE, Mário. Romances Rurais. Recife: Ed. do Organizador, 2005, p. 136 (título do romance: Senhora de Engenho).

${ }^{5}$ SETTE, Mário. Romances Urbanos. Recife: Ed. do Organizador, 2005, p. 267 (título do romance: Seu Candinho da Farmácia).

${ }^{6}$ Sobre redes sociais, ver MATOS, Ralfo; BRAGA, Fernando. "Redes sociais, redes territoriais e migrações", p. 121. Disponível em: http://www.abep.nepo.unicamp.br/site eventos abep/PDF/ABEP2004 113.pdf. Acesso em: 15/2/2011. Trabalho apresentado no XIV Encontro Nacional de Estudos Populacionais, ABEP, Caxambu MG, Brasil, 2004.

${ }^{7}$ APEB, Seção Judiciária, Série Estupro, Estante 192, cx. 8, doc. 2. Estupro de Maria de Jesus. Réu: José Pereira Pinto. Bahia, 1900, fl. 2. Citado sempre Estupro de Maria de Jesus, seguido da folha.
} 
um ano inteiro, após ser entregue pela mãe, que morava na Barra da Estiva. Em Vitória da Conquista, vivia "sendo constantemente maltratada por ele e pela mulher, que frequentemente the batiam, chegando muitas vezes o tal soldado a Ihe queimar as mãos, aquecendo a frigideira e colocando nela suas mãos" ${ }^{8}$. Castigos desse tipo podiam, de fato, compor o triste espetáculo da rígida formação de uma futura doméstica.

Com a mudança para Salvador, vieram habitar o beco das Quebranças, na freguesia da Vitória, lugar habitado, em geral, por grandes senhores, negociantes enriquecidos e estrangeiros abonados ${ }^{9}$. O pior ainda estava por vir. Com o pretexto de ir buscar sua refeição em uma casa de pasto na rua Politeama, o soldado levou Maria consigo e, dentro de umas matas que ainda existiam no caminho, estuprou- $\mathrm{a}^{10}$.

O tom comovido e revoltado com que o Promotor apresentou a denúncia está de acordo com novos valores que então se formavam na consciência dos intelectuais mais ilustrados da época. Muitos juristas do final do século XIX estavam convencidos da importância do Judiciário na construção de uma "civilização dos bons costumes", a partir de um conjunto de normas legais que formavam uma pedagogia que inspirasse práticas e valores sadios. Combater os crimes sexuais, proteger a honra das famílias era um modo de proteger o próprio corpo social ${ }^{11}$. Atos desta natureza, que atentavam contra a dignidade humana e os valores da República, davam margem a expressões condenatórias fortes "furor bestial", "perversidade", "monstruosidade" - e ensejavam indignação e punição ${ }^{12}$.

Algumas histórias, contudo, podem mostrar a fragilidade desta "civilização dos bons costumes" em Salvador e Recife. Não que o exercício do serviço doméstico por crianças e adolescentes fosse algo aberrante para os valores vigentes nas principais cidades brasileiras do período. Pode-se mesmo dizer que fazia parte de certa pedagogia da infância colocar meninos e meninas desde cedo para executar atividades domésticas, especialmente quando marcados pela pobreza e pelo abandono. As décadas finais do século XIX e do início do XX, no Brasil, constituem um momento histórico em que o trabalho foi elevado à categoria de "princípio regulador da sociedade", como conceito irmão de outros como civilização, ordem, progresso $^{13}$. Esse conceito de trabalho, fortemente pregado no Brasil da época, abrangia o ingresso precoce de crianças e adolescentes das camadas populares em diversas formas de

\footnotetext{
${ }^{8}$ Estupro de Maria de Jesus, fl. 6 v.

${ }^{9}$ A Rua das Quebranças era, provavelmente, um beco, e devia ser um simples prolongamento da Rua do Faísca, endereço de boa parte das testemunhas. A freguesia como um todo, um arrabalde até então, não era muito urbanizada. Por volta de 1855, pelo menos, ela tinha apenas 674 casas. Era uma "freguesia de elite", com uma quantidade de escravos domésticos bastante alta nos idos de 1855. Ver VIEIRA NASCIMENTO, Anna Amélia. Dez freguesias da cidade do Salvador: aspectos sociais e urbanos do século XIX. Salvador: EDUFBA, 2007, p. 69 e p. 120-124.

${ }^{10}$ Estupro de Maria de Jesus, fl. 2v.

${ }^{11}$ ESTEVES, Martha de Abreu. "Meninas perdidas", p. 289-316. In DEL PRIORE, Mary (org.). História das crianças no Brasil. 6a ed. São Paulo: Contexto, 2008, p. 292.

${ }^{12}$ Estupro de Maria de Jesus, fl. 2v.

${ }^{13}$ Ver CHALHOUB, Sidney. Trabalho, lar e botequim: o cotidiano dos trabalhadores no Rio de Janeiro da belle époque. 2a ed. Campinas, SP: Editora da UNICAMP, 2001, p. 48-49.
} 
trabalho, fosse nas fábricas, fosse no serviço doméstico ${ }^{14}$. É óbvio que a situação vivida por Maria de Jesus, com o desfecho que teve, não tinha nada de abonador para a ideia de trabalho e de ordem que se previa. Seja como for, é preciso deixar evidente que a história do trabalho doméstico, como já indicou Bridget Hill, cruza-se perfeitamente com o tema da história das crianças e jovens ${ }^{15}$. Logo, o tema do trabalho, quando no âmbito doméstico em especial, impõe incluir o componente geração na análise ${ }^{16}$.

Maria de Jesus, como dito, encerra um caso limite. Mas, apesar de toda a sua singularidade, ele pode iluminar as experiências de outras crianças e adolescentes, sem suporte familiar, sem vínculos com parentes próximos, em ambientes que thes eram estranhos, trazidos de regiões distantes para centros urbanos brasileiros. O caso dela também ensina sobre o modo como os grupos populares reagem e se mobilizam diante de quadros dramáticos. Diante das cenas e fatos grotescos que violam os códigos populares de conduta, como mulheres domésticas se posicionavam? Que vínculos de gênero e classe eram mobilizados para intervir em dramas como o de Maria de Jesus?

Casos como o de Maria de Jesus não são esquecidos facilmente. A memória popular guarda e amplia estas narrativas exemplares que fazem recordar dramas e situações perigosas, aventuras de heróis e vítimas. Os sentimentos despertados por estas narrativas são os mais diversos. Em alguns casos, brotam a admiração e o assombro pela valentia, pela ousadia diante de confrontamentos com a ordem; em outros, repúdio, indignação, revolta, medo. Raptos, defloramentos, estupros, gestos ousados, furtos, violências, compõem o leque de temas caros nas conversas íntimas entre os populares. Maria de Jesus e sua triste história comoveu e moveu os personagens envolvidos. Ela era uma criança, e seu estupro rompeu todos os códigos de conduta do grupo. Como Claudia Fonseca percebeu, no meio popular, atos de violência seguidos de narrativas são comuns. Mas não é todo tipo de violência e ato sexual que são admirados: "Existem atos de violência que não são admirados - atos interpretados como covardia. Assaltar a casa de um vizinho, estuprar uma criança, bater num velho ou em uma mulher grávida - nada disso é permitido pela moralidade pública"17. O destino de Maria, irremediavelmente afetado pela violência de um homem adulto, superior em forças, no lugar de poder de pai/padrasto, mexia com todos, sobretudo com as mulheres pobres adultas. Elas também tinham ou teriam filhas, e não queriam que acontecesse algo tão terrível com elas.

\footnotetext{
${ }^{14}$ Ver MOURA, Esmeralda Branco. “Crianças operárias na recém-industrializada São Paulo”, p. 259-288. In DEL PRIORE, Mary. (org.). História das crianças no Brasil. 6ạ ed. São Paulo: Contexto, 2008.

${ }^{15}$ HILL, Bridget. "Algumas considerações sobre as empregadas domésticas na Inglaterra do século XVIII e no Terceiro Mundo de hoje", p. 22-33. In Vária História, Belo Horizonte, no 14, Set/ 1995, p. 22.

${ }^{16}$ Não é sem razão que o trabalho infantil doméstico, no Brasil de hoje, está incluído como uma das piores violações aos direitos humanos. Estima-se que 190 mil meninas estejam nesta condição. Ver SANCHES, Solange. "Trabalho doméstico: desafios para o trabalho decente". Estudos Feministas. Florianópolis, 17 (3), 879-888, setembro-dezembro/2009.

${ }^{17}$ Ver FONSECA, Claudia. Família, fofoca e honra: etnografia de relações de gênero e violência em grupos populares. 2a ed. Porto Alegre: Ed. da UFRGS, 2004, p. 184.
} 
Além do furriel baiano, Miguel dos Santos Magalhães, e do praça do primeiro corpo da Brigada Policial, o mineiro João Pereira da Silva, envolveram-se no caso a doméstica Maria Antonia da Piedade, a lavadeira e engomadeira Maria Bernardina da Conceição e a costureira Maria Jose da Annunciação, filha da lavadeira Bernardina. Piedade tinha nascido mesmo em Salvador, era analfabeta, solteira e tinha 28 anos de idade; Bernardina era natural "da Mata de São João d'este estado", também analfabeta e solteira, e tinha 30 anos de idade; a filha desta última era já casada, tinha 15 anos, baiana (não diz se de Salvador ou de Mata de São João), e era analfabeta como a mãe.

Os testemunhos das domésticas, em conjunto, assinalam profunda solidariedade para com a criança estuprada. Os sentimentos de família e amizade demonstrados são devidos mais à condição comum de pobreza e ao senso de proteção devido aos mais fracos, do que a laços de parentesco formalmente constituídos. Elas esposam sentimento de família, deveres para com os mais fracos, não obstante viverem em relações consensuais com seus amásios. Segundo elas, tudo foi muito rápido. Maria Antonia da Piedade era a proprietária do quarto que o réu pediu para alugar no beco das Quebranças. A doméstica, entretanto, "não querendo alugar quarto deu-lhe hospitalidade em uma sala por muito interesse d'eles". Pelo que dá a entender, a família continuava vivendo neste cômodo. Entre quarta-feira da "semana passada", quando eles se alojaram, e a segunda-feira à noite da semana seguinte - dia 23 de julho - em que se deu o estupro. As testemunhas, por sua vez, foram inquiridas no dia 27 de julho, na sexta-feira, ainda na mesma semana do crime.

José Pereira Pinto teria ido buscar sua comida em uma casa do Politeama, pertencente a certa Lucia, e levou consigo a menina. Dentro de uma hora, ele retornou com a menina, que estava com a camisa e a saia ensanguentadas, e contusões no rosto. A doméstica Piedade perguntou o que tinha acontecido, e ela, amedrontada, falou ter sofrido uma queda. A experiência popular em assuntos tão delicados como este foi acionada, e ela conclui: "esta menina foi forçada!". Ela teria visto "as partes" gotejando sangue, e o soldado não falou nada, nem deu algum medicamento, o que seria, para ela, "natural". Ora, aqueles que se incumbem da proteção de alguém devem, pelos valores da época, garantir tratamento médico aos protegidos. O povo parece muito consciente deste tipo de direito, e cobra isso mesmo de uma família apenas remediada. Se assumiu para serviços domésticos, que dê o mínimo, que é medicação na doença. Seguiu-se uma discussão em que as mulheres presentes, todas domésticas, invocaram sua condição de "mães de família", e enfrentaram o soldado. Ele disse "Vocês não provam que fui eu". As mulheres retrucaram "que elas todas eram mães de família e não podiam deixar passar aquilo assim". A vizinha de Piedade, a lavadeira e engomadeira Maria Bernardina, resolvera procurar seu amásio, João Pereira da Silva, praça da Brigada Policial. Talvez o tempo estivesse fechando, e as mulheres sentissem que era preciso a presença de outro homem para evitar um eventual confronto físico. A noite de segunda para terça-feira foi tensa. Quando, por fim, João chegou, recomendou que Piedade "vigiasse a menina e a mulher do soldado que se ele viesse não abrisse a porta, dizendo a ela que tirasse a chave". O amásio de Sinhá Maria, como soldado, montou uma 
estratégia para evitar o retorno do estuprador. No meio da noite, contudo, o estuprador entrou pela janela, pegou seus objetos e fugiu com sua mulher, ficando a menina aos gritos na cama. Na manhã da terça-feira, o soldado João conduziu a menina à Polícia.

Maria Antonia também contou que Sinhá Maria, tendo ido levar roupa ao quartel, um furriel disse que tinha visto uma menina nos matos do Politeama, "em pé chorando e com as mãozinhas nas partes e um soldado perto" ${ }^{18}$. Sinhá Maria, além de amásia de um soldado, era lavadeira e engomadeira de outros soldados que constituíam sua freguesia. Por fim, Piedade relatou que, com o auxílio de Sinhá Maria, trataram da menina como puderam: em uma bacia de água, banharam "as partes d'ela que estavam inflamadas e machucadas e feridas d'onde saía bastante sangue ${ }^{19}$. As duas vizinhas, domésticas, mães de família, na certa pensavam que algo assim poderia também ocorrer a uma filha sua. Era preciso se unir para minimizar os riscos. Não apenas a honra fora violada. A própria vida da menina corria risco $^{20}$. Os médicos, depois, viriam confirmar o triste quadro que a experiência popular já sabia $^{21}$. A engomadeira e lavadeira Maria Bernardina foi uma das que examinou a menina, observando a vestimenta, o sangue que se estendia até a parte de trás da roupa. Interrogando Maria de Jesus, esta disse que tinha sido uma queda, e que "tinha entrado um pau até o ventre", ao que Bernardina, junto da autoridade policial, acrescentou: "e isto tudo disse muito amedrontada" 22 .

Depois de conversar com a vizinha e saber que Maria de Jesus saíra à noite em companhia do soldado, sentenciou: "qual queda, esta menina foi forçada"; a julgar pelo depoimento de Bernardina, foi ela a principal heroína em defesa da menina. Antes de seu amásio chegar do trabalho, fora ela e Piedade que cerraram trincheiras contra o estuprador. Ao soldado, ela enfrentou e sustentou que ele era mesmo o causador do sofrimento da menina; e acrescentou também que sua condição de mãe de família não podia fazê-la compactuar com o caso ou silenciar diante dele. Em seguida, foi procurar seu amásio para prestar apoio ante a atitude ameaçadora do soldado. Bernardina foi lembrando aqui e ali fatos ouvidos. Por exemplo, a gravidade do crime seria tal, que o próprio ofensor teria conduzido a vítima nos braços até perto de casa, porque Maria de Jesus, simplesmente, não tinha condições de andar. Isso Bernardina teria sabido da própria vítima ${ }^{23}$.

De um ponto de vista geral, as mulheres são as primeiras a acudir em situações de defesa da honra, que é um valor importante mesmo entre as camadas populares. Agora sob risco iminente de um enfrentamento físico, tanto Piedade quando Bernardina julgaram melhor procurar um outro homem para equilibrar a balança em seu favor. Foram corajosas e

\footnotetext{
${ }^{18}$ Estupro de Maria de Jesus, fls. 17v-18.

${ }^{19}$ Estupro de Maria de Jesus, fl. 18.

${ }^{20}$ No meio de tantas Marias, ainda não pude identificar quem é a tal "Sinhá Maria". O mais provável é que fosse o apelido comum de Maria Bernardina e de Maria Antonia da Piedade. A confusão, pelo que entendi, é gerada pelo fato de ambas se chamarem mutuamente de Sinhá Maria em seus depoimentos.

${ }^{21}$ Ver Estupro de Maria de Jesus, fl. 9.

${ }^{22}$ Estupro de Maria de Jesus, fl. 19.

${ }^{23}$ Estupro de Maria de Jesus, fl. 20v.
} 
ousadas, mas não eram bobas. Preferiram se prevenir do provável ódio de José Pinto. As domésticas estavam na defesa não da honra em particular, mas da honra em seu sentido coletivo, e que a ação de José Pinto pôs em risco ${ }^{24}$. Toda a comunidade do beco das Quebranças foi ofendida com o ato do forasteiro.

A amásia do réu, em toda a história, parece não ter mostrado muita preocupação com Maria de Jesus. Não teria mesmo sequer ficado com raiva do amásio, segundo o depoimento de Bernardina. De fato, as testemunhas, que praticamente dividiam os mesmos cômodos do beco das Quebranças, foram unânimes em afirmar que ela fugira com o réu na madrugada posterior ao estupro, pela janela da casa de Piedade, onde a menina e a amásia passavam a noite de segunda-feira. O soldado, que tinha fugido antes de João chegar, voltou pela madrugada para buscar a amásia, deixando a menina, que vira tudo, gritando, em estado de choque. Saudável e submissa, Maria de Jesus podia até ser útil aos dois realizando tarefas domésticas simples e aprendendo as mais complexas e cansativas. Doente e vilipendiada, abandonaram-na à caridade alheia.

O documento que tenho em mãos se prolonga apenas até o final do inquérito. Contra José Pinto fora expedido mandado de prisão preventiva para ser cumprido pelo Coronel que comandava a Brigada Policial. O que torna o caso de Maria de Jesus singular e mais chocante, quando comparado a outros, é um conjunto de variáveis: a idade dela, o estado deplorável em que fora encontrada pelas testemunhas, o fato de ter sido estupro e não simples defloramento, a inexistência de algum envolvimento romanesco entre ofensor e vítima (promessa de casamento, logro, bilhete, sedução). Casos de defloramento de domésticas, mesmo quando bastante provados materialmente, davam margem a muita subjetividade de todas as partes envolvidas, e as autoridades policiais e judiciais observavam intenções, gestos, prováveis consentimentos, deslocamentos espaciais dos envolvidos, as formas, enfim, como se deu o "namoro". Nestas situações, portanto, a solidariedade de gênero pode ser bem mais tênue e vacilante, e mulheres adultas, mesmo se domésticas como a vítima, podem não apoiar integralmente uma ação de reparação da honra. Com Maria de Jesus tudo muda. Não há como transferir para a vítima qualquer malícia, e não há honra a reparar. As domésticas Bernardina e Piedade praticamente assumiram-na como filha. Como não tenho o prosseguimento da ação judicial, não posso sequer vislumbrar o destino de Maria de Jesus. Permaneceria no meio popular que o auxiliou?

Com a criada paraibana, que discutirei abaixo, de 12 ou 13 anos, vivendo na condição de simples agregada na casa de um alagoano residente no Recife, a história é bem outra. $A$ sua idade, o namoro, as promessas de casamento, a possibilidade de fugir da casa onde vivia como empregada doméstica, a distância de parentes reais ou fictícios, tudo contribuiu para ela não obter maiores solidariedades. A primeira relação sexual, neste caso, lança a

\footnotetext{
${ }^{24}$ Para o sentido coletivo da honra e a punição que se deve a um membro que a infringe, ver PITT-RIVERS, Julian. "Honour and social status", p. 19-77. In PERISTIANY, J. G. (org.) Honour and Shame: the values of mediterranean society. The University of Chicago Press, 1974, p. 35-36.
} 
doméstica em uma vida de ambiguidades: fora seduzida? Deixou-se seduzir? Acreditava-se, neste momento da vida, que ela poderia já fazer escolhas.

A criada paraibana se chamava Galdina. A denúncia fora de estupro. A denúncia datava de maio, mas o fato teria ocorrido em fevereiro de 1910. No dia 6 de maio, Architriclino Augusto de Hollanda, um comerciante casado, nascido em Alagoas, morador na Rua Imperial, no Distrito de São José, em Recife, tomou para si a responsabilidade de perseguir o ofensor de sua agregada ${ }^{25}$.

Galdina era filha de certo Jose Goulard, já falecido, tinha doze anos de idade e era analfabeta. No auto de perguntas, referira-se a Hollanda como seu "protetor patrão". Foi a ele que ela recorreu quando viu que Eduardo não se resolvia a casar. Ela afirmou estar desvirginada "sob promessas de casamento" desde fevereiro, e assim justificou seu consentimento para o ato sexual:

\begin{abstract}
que anteriormente recebera diversos presentes de Eduardo, que durante três ou quatro meses namorou, com o indivíduo Eduardo dos Reis, que consentiu que o indivíduo Eduardo dos Reis a deflorasse porque estava certa de casar-se com ele, em vista das provas de amizade que ele manifestara diferentes vezes, falando-lhe sempre do seu próximo casamento, [...] que como [...] não procurasse realizar o casamento prometido ela respondente resolveu queixar-se ao seu protetor patrão $[\ldots]^{26}$.
\end{abstract}

Em que consistia essa proteção? Além do fato inegável de que o alagoano estava lutando para reparar a honra de sua doméstica, tem-se a fala das testemunhas. José Luiz Gonçalves Pereira, negociante que tinha intimidade com a família de Hollanda, disse no inquérito "que sabe por ter presenciado várias vezes que o senhor Hollanda tem por costume trancar todas as noites, todas as suas empregadas, e soltando-as pela manhã". No processo já instaurado, o conteúdo muda pouco: "sabe por lhe ter dito o mesmo Hollanda e diversas pessoas de sua família que era costume do chefe da casa trancar as referidas menores afim de evitar bandalheiras fazendo o mesmo com as demais empregadas; que o senhor Hollanda é homem de bons costumes" ${ }^{27}$. Curioso modo de preservar a honra das empregadas. Mesmo tempos depois de abolida a escravidão, o comerciante alagoano tinha costumes não muito progressistas com suas empregadas. Por isso muitas criadas preferiam dormir em suas próprias residências, evitando esse aprisionamento ${ }^{28}$. Sem dúvida, isso explica por que Galdina e outra agregada, também menor, de nome Severina, fugiram juntas da casa do comerciante para Jaboatão. A figura do patrão protetor converte-se, não raro, em algoz e feitor. Severina, inclusive, na fala de outra testemunha, recusou-se, quando

\footnotetext{
${ }^{25}$ Instituto Arqueológico, Histórico e Geográfico Pernambucano. Denúncia contra Eduardo Daniel dos Reis, Pernambuco, 1910, Cx. (alterada, sem condições de identificação), fls. 5-5v. De agora em diante, citado Denúncia, seguido da numeração da folha.

${ }^{26}$ Denúncia, fls. 6-6v.

${ }^{27}$ Denúncia, fls. 14 e 28.0 grifo está no original.

${ }^{28}$ Ver SILVA, Maciel Henrique. Pretas de honra: trabalho, cotidiano e representações de vendeiras e criadas no Recife do século XIX (1840-1870). Dissertação (Mestrado em História), Universidade Federal de Pernambuco. Recife, 2004, p. 252.
} 
encontrada por Hollanda, a voltar à casa dele, e "ficou em casa de uma família daquela

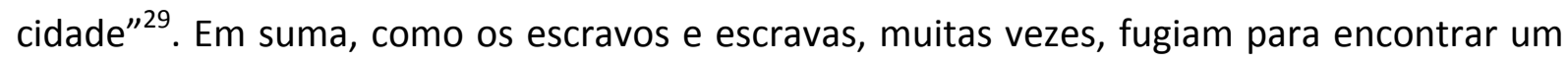
"senhor melhor", Severina também julgou encontrar uma "família melhor", e acionou uma antiga prática de resistência, mas que funcionou. ${ }^{30}$ É provável que Galdina só tenha retornado para ver se conseguia do patrão apoio para lutar por seu casamento. Ficar na casa desta família de Jaboatão, ou não era possível, ou ela preferia um provável casamento. Era preciso fazer uma escolha, e ela o fez. Ter em casa meninas menores, teoricamente sob proteção, talvez fosse mesmo considerado mais vantajoso para a exploração do trabalho do que ter criadas adultas, com experiências e regras próprias de como negociar a relação de trabalho.

O estupro foi comprovado pelos peritos, que consideraram Galdina como uma parda de 12 anos de idade. 0 ato sexual, embora aparentemente consentido, foi violento ${ }^{31}$. Tudo leva a crer que havia mesmo uma relação de namoro entre a doméstica e o jovem. Eduardo Daniel dos Reis era um rapaz de apenas 19 anos de idade, solteiro, pernambucano, empregado da Great Western, analfabeto, que morava em Afogados, bairro próximo do centro do Recife, de população majoritariamente pobre. Ele reconheceu namorar com Galdina havia pelo menos três meses, e que passava todas as tardes, provavelmente após o dia de serviço, em frente à casa do comerciante, mas sem frequentar a casa. Negou, portanto, haver contatos maiores entre os dois. Por fim, disse que não era o deflorador, "mesmo porque nunca estivera a sós com ela", e que não sabia quem foi o autor do defloramento $^{32}$. Ele era natural do Cabo, município da Zona da Mata Sul pernambucana.

Além de José Luiz, outros negociantes depuseram. Mas o depoimento deste foi, sem dúvida, o mais completo, em virtude do grau de intimidade entre ele e a família Hollanda. Antonio Cordeiro de Lima, de 27 anos, alfabetizado, disse que frequentava a casa acompanhando seu amigo João Bello, sem ter, portanto, maior contato com a família. Entretanto, sabia de algumas informações. Sobre Galdina, disse que nada sabia "em desabono de sua conduta", e que tinha vindo de Itabaiana para a casa de Hollanda com apenas seis anos de idade. Hollanda, contudo, falou que estava com a adolescente há dois anos, logo ela teria vindo para o Recife aos dez anos ${ }^{33}$.

José Luiz trouxe mais luz ao caso, sobretudo quanto ao tema dos presentes que Galdina teria supostamente recebido. Em um jantar na casa da família, soube que a sogra de Hollanda, puxando Galdina para si, interrogou-a, e ela teria confessado "ser autor de ditos presentes o denunciado presente e ainda ser responsável pelo seu estupro". Na Justiça,

\footnotetext{
${ }^{29}$ Denúncia, fl. 29v.

${ }^{30}$ Sobre o tema dos escravos e escravas, ver CARVALHO, Marcus J. M. de. Liberdade: rotinas e rupturas do escravismo no Recife, 1822-1850. Recife: Editora Universitária da UFPE, 1998, p. 271-310. Sobre fugas constantes, ainda no século XIX, de agregadas trazidas dos engenhos e que trabalhavam em casa de membro da tradicional família Cavalcanti em Pernambuco, ver FREYRE, Gilberto. O velho Félix e suas "Memórias de um Cavalcanti". Rio de Janeiro: Livraria José Olympio Editora, 1959, p. 109 e 110.

${ }^{31}$ Denúncia, fl. $9 \mathrm{v}$.

32 Denúncia, fl. 11.

${ }^{33}$ Denúncia, fls. 25 e 5.
} 
Daniel negou ter comprado objetos para Galdina (manafas ou marrafas, e uma pulseira de prata). Ele teria declarado "que tais objetos não foram por ele presenteados e sim comprados a pedido e com o dinheiro de Galdina, sendo certo que ele denunciado tinha em seu poder mais dez objetos que Maria lhe dera para guardar"34. José Luiz disse que sabia, "por informações", que a menor não tinha recursos próprios. Já no depoimento anterior, dissera ao delegado que "tinha ciência" de que Galdina "entretinha namoro com Eduardo Reis" ${ }^{35}$. Ou seja, os presentes não poderiam ter outra origem que não Eduardo. José não considerava que uma simples agregada, que trocava serviços domésticos por alimentação e vestuário (seria essa a forma de pagamento), pudesse ter meios para comprar para si objetos de adorno pessoal.

Mas há outras possibilidades de se descortinar a origem de tais "presentes". José Luiz disse que o alagoano vivia da vendagem de um produto que eu não soube identificar, "tendo para esse fim, diversas empregadas e empregados" ${ }^{\prime 36}$. Pode-se imaginar que Galdina, que nada recebia do patrão além de alimentação e vestuário, tirava para si parte do lucro dessa vendagem como forma suplementar de pagamento, e como não poderia guardar o dinheiro, pedia para Daniel comprar e guardar objetos como forma de poupança. Não sendo Daniel o galanteador apaixonado que disseram ser, então essa não é uma possibilidade a se desprezar. Sei que essa interpretação dá a Galdina uma maturidade difícil de encontrar em pessoas de sua idade. Mas o tom do documento me levou a imaginar algo como um plano de fuga entre os namorados, e Daniel pode mesmo ter, a princípio, influenciado a doméstica para comprar tais objetos, pensando em se dar bem.

O pernambucano Deodato morava em São José, como Hollanda, e também vivia do comércio. A família de Hollanda contava para ele a velha história de que a mãe de Galdina, moradora em Itabaiana, e sem "recursos para prover a subsistência da mesma menor", teria pedido a Hollanda para a filha viver em sua casa. Ele também repetiu a história da fuga das duas agregadas ${ }^{37}$. Quando Hollanda passou a residir na Rua Imperial, Deodato o visitava com frequência e "teve ocasião algumas vezes de ver entre outras muitas menores ocupadas em diversos misteres domésticos a menor ofendida, que teria uns doze anos de idade ${ }^{\prime 38}$. Sobre a fuga, contou a história que Galdina contara à família e que assim resumiu: enquanto Severina ia mais à frente, Galdina "ficou a conversar na esquina de uma casa, no fim da rua, em entrevista com o referido Eduardo." Isso tudo teria acontecido pela manhã ainda, provavelmente antes de Eduardo se dirigir ao trabalho. Nesta ocasião ocorreu o

\footnotetext{
${ }^{34}$ Denúncia, fl. 27.

${ }^{35}$ Denúncia, fl. $13 \mathrm{v}$.

${ }^{36}$ Denúncia, fl. 27v. Uma transcrição equivocada poderia entender como "rendagem" o meio de vida de Hollanda. $O$ trecho está de difícil leitura. Mas a presença de várias pessoas trabalhando em sua casa leva a crer que havia uma pequena produção doméstica.

${ }^{37}$ Denúncia, fl. 28-31.

${ }^{38}$ Denúncia, fl. 29.
} 
defloramento, e Eduardo a teria convencido a fugir sozinha, dado que ele teria de "desempenhar suas obrigações de jornaleiro da Great Western"39.

$\mathrm{Na}$ idade de Galdina, a partir dos doze anos de idade, já era conveniente perguntar-se pela conduta moral de uma adolescente. Para uma criança como Maria de Jesus, como discutido, presume-se a inocência. Para uma adolescente, ainda que sete anos mais jovem do que seu estuprador, a suspeita de que ela fora ativa e pouco decorosa era encarada como normal. O "comportamento honesto", segundo Martha Esteves, é fulcro do discurso jurídico relativo aos grupos populares e seu cotidiano. Interessa não só o fato material de estar ou não virgem. O "procedimento", tanto passado como presente, é objeto de esquadrinhamento $^{40}$. Joaquim Moreira e Antonio Cordeiro foram questionados sobre o comportamento da agregada Galdina. O primeiro disse que não sabia nada; o segundo afirmou "que nunca ouviu falar que a ofendida tivesse outros namorados, digo tivesse namorados" $" 1$.

As investigações da Delegacia de São José começaram no dia 6 de maio. No dia 18, Eduardo já estava em liberdade por ordem do Delegado. Provavelmente logo após responder ao primeiro interrogatório, no dia 9, ele fora solto. Quando o juiz tentou intimálo, junto com as demais testemunhas, no dia 17, julgou que ele estivesse na Casa de Detenção. Mas se enganou. A maneira como ele se libertou tão rapidamente não está esclarecida. Só sei que o administrador interino da Casa de Detenção, no dia 18 de maio, comunicou ao juiz que o Delegado do 1 - Distrito da Capital tinha ordenado sua liberdade. Seja como for, Eduardo não estava desaparecido, e foi encontrado para novo interrogatório no dia 23. Mas o último interrogatório de Eduardo se deu apenas no dia 20 de julho. Em um interrogatório bastante leve, não foi perguntado se foi o autor do estupro. A pergunta mais contundente foi onde ele estava "durante o tempo em que se diz ter acontecido o crime"... Evadiu-se com a resposta simples de que estava em sua casa, em Afogados ${ }^{42}$. Como o defloramento ter-se-ia dado pela manhã, segundo o depoimento de Deodato, momento em que Eduardo estaria, acredito, dirigindo-se para o trabalho, esta afirmação de que ele estava em casa deveria ser, ao menos, posta em suspeição. Até mesmo porque a freguesia de São José era passagem obrigatória para quem ia de Afogados para a parte mais central da cidade. Mas não foi o caso ${ }^{43}$.

A história de Galdina se encerra com uma aula de Direito da parte do Curador de Eduardo. Citando todos os autores jurídicos à mão, inclusive o ilustre jurista Viveiros de Castro, e recorrendo a textos legais produzidos ainda no século XIX e mesmo no XVIII acerca das provas relativas à miserabilidade, à menoridade e acerca das ações de caráter público e

\footnotetext{
${ }^{39}$ Denúncia, fl. 30.

${ }^{40}$ Ver ESTEVES, Martha de Abreu. Meninas perdidas: os populares e o cotidiano do amor no Rio de Janeiro da Belle Époque. Rio de Janeiro: Paz e Terra, 1989, p. 39-43.

${ }^{41}$ Denúncia, fls. 35 e 25-25v.

${ }^{42}$ Denúncia, fl. $48 \mathrm{v}$.

${ }^{43}$ Afogados também era caminho para Jaboatão, caminho onde pululavam mocambos de palha. Ver romance do período de VILELA, Carneiro. A emparedada da Rua Nova. 4ạ ed. Recife: Ed. do Organizador, 2005, p. 104.
} 
privado, o Curador teve sucesso na defesa do réu. Não vou me alongar aqui enumerando os argumentos da defesa, de resto muito bem construídos. Mas cabe discutir o pensamento jurídico neles expresso de modo tão didático, uma vez que sumariza uma leitura formalista e conservadora dos textos da lei. Do ponto de vista social, pode-se até afirmar que Galdina recebia alguma proteção de Hollanda, e este, de fato, dirigira-se à delegacia de São José para resolver o caso. Na esfera jurídica, contudo, a doméstica não tinha representante legal para se defender. Não importa aqui a vontade do alagoano em exercer a prerrogativa patriarcal da defesa da honra dos membros de sua casa. Ele não era tutor dela, nem designou ninguém para sê-lo. Ela era apenas agregada, não uma tutelada legal. A mãe, que as testemunhas diziam existir e morar em Itabaiana, não movera a ação, e o Ministério Público só poderia fazê-lo se Galdina tivesse algum representante legal para prestar a queixa, ou se ela fosse considerada miserável, o que o Curador contestou. Em suma, ela estava agregada, mas não protegida oficialmente ${ }^{44}$.

Formalmente, do mesmo modo, os atestados de miserabilidade e de menoridade não tinham sustentação jurídica. Miserável não é qualquer pessoa pobre, é aquela pessoa que pode provar sua incapacidade de perseguir juridicamente seu ofensor. No processo, ninguém pedira tal atestado, e quem o forneceu foi a autoridade policial, inapta para fazê-lo, considerando Galdina miserável pelo fato de ela prestar serviços domésticos. Sem falar que, nos crimes de natureza privada, só após a prova da miserabilidade é que se podem iniciar os autos de perguntas, e o delegado não esperou essa formalidade. Quanto à menoridade, no Império, bastava uma certidão de batismo, e o pároco podia resolver isso. Na República, a certidão do Registro Civil valeria. Infelizmente, para Galdina, foi o Juiz quem atestou sua menoridade, o que não podia fazê-lo também. E o atestado nem a idade precisa da vítima continha, o que era dado essencial para caracterizar, na época, se o crime seria de estupro ou defloramento. Só as testemunhas diziam que ela era "de menor", mas isso também não constituía prova positiva. O Curador sentiu-se à vontade para reconhecer que ela estava realmente desvirginada, como o único dado confiável em todo o caso ${ }^{45}$. Ficou, em suma, a palavra de Galdina (reproduzida pela família e passada desta para as testemunhas), contra a palavra de Eduardo. Formalidades jurídicas são armas de dois gumes, claro. Juristas mais progressistas podiam até passar por cima de alguma dessas formalidades, mas, de resto, as ferramentas jurídicas disponíveis eram mais manipuláveis por quem defendia réus acusados de crimes sexuais. Havia mesmo um consenso jurídico de que ficar calado era melhor para a "paz das famílias", do que o escândalo advindo de uma ação judicial de reparação da honra ${ }^{46}$.

Mas seria enganoso creditar a derrota de Galdina, simplesmente, ao notável saber jurídico do advogado. E ela também não perdeu sozinha. Minha conclusão é de que Hollanda sofrera um duro golpe em seu direito patriarcal de pelejar pela honra dos agregados de sua

\footnotetext{
${ }^{44}$ Denúncia, fl. 52.

${ }^{45}$ Denúncia, fl. 57.

${ }^{46}$ Denúncia, fl. 50v.
} 
casa. Se sua doméstica fosse escrava ou, ao menos, tutelada, o direito lhe era inerente. Sendo livre e agregada, com mãe distante geograficamente, e órfã de pai, Galdina, de fato, não estava sob a proteção oficial de ninguém.

Vale não esquecer que Galdina, mesmo adolescente, teve a coragem de empreender uma fuga arriscada e com certo planejamento. O estupro, claro, não constava nos planos. A ausência de Eduardo, após o fato consumado, muito menos. Mas ela sabia dos riscos de sair da autoridade de seu patrão e mesmo assim seguiu em frente. Sua desilusão, quem sabe, fora bem real, já que sua aventura de fuga não foi bem-sucedida. Vivendo cerceada na casa do "protetor patrão", ela vira na relação amorosa, provavelmente, um modo de abrir territórios tanto físicos como simbólicos para si. Na prática, vivia aprisionada e, quando julgou que podia se dar bem, fugindo, pode ter sofrido uma desilusão amorosa e retornou para o convívio do patrão. Teria Eduardo prometido encontrá-la após o dia de serviço na Great Western? Se prometeu, não cumpriu, nem assumiu nada. A rebeldia de Galdina, contudo, deve ser notada.

\section{PARDAS E LAVADEIRAS NOS SUBÚRBIOS DE RECIFE}

Pardas, lavadeiras, Maria Vapor e Maria Jacintha do Nascimento habitavam algum casebre na "Ilha do Fernandinho", segundo distrito de São José. Vizinhança estreita, mesma comunidade, grupos de trabalhadores diversos, elas até lavavam roupa no mesmo rio. Cenário que podia ser de solidariedades, e provavelmente também era, mas que foi palco de sério conflito entre ambas e seus homens, que resultou na morte de Maria Vapor e do carroceiro pardo José Anastácio de Oliveira. Como se vê, só há pardos nessa história, habitando um território afastado do centro do Recife, mas não muito distante ${ }^{47}$. A localidade era habitada por gente apenas remediada e muitos pobres. É razoável imaginar um contingente não desprezível de pardos e mestiços ocupando precárias habitações à beira do rio.

Maria Jacinha e Maria Vapor eram dessas mulheres que lavavam roupa de ganho, com clientes mais ou menos fixos, sem que quisessem ou pudessem trabalhar em casas de família. Maria Jacintha, junto com seu amásio Pedro Alexandrino da Silva, teria assassinado sua companheira de trabalho. Pedro Alexandrino, vulgarmente conhecido como "Pedro Ventania", fez jus ao nome e desapareceu, não sendo mais encontrado pela polícia; Jacintha, ao contrário, respondeu ao processo reclusa na Casa de Detenção do Recife. A história, que começou com uma briga de lavadeiras, terminou em uma tragédia. Maria Jacintha, solteira, de apenas 17 anos, era companheira de trabalho de Maria Xavier, conhecida por Maria Vapor. Juntas, foram lavar roupa no rio Tejipió. Jacintha teria encontrado um par de rosetas

\footnotetext{
${ }^{47}$ As vítimas do assassinato também foram apresentadas como crioulos. Ver Memorial de Justiça de Pernambuco, Denúncia de assassinato contra Pedro Alexandrino da Silva ("Pedro Ventania”) e Maria Jacintha do Nascimento, Pernambuco, 1902, Estante 26, A 5. A seguir, citado Denúncia, seguido da folha.
} 
de coral com pérolas "pertencente a uma senhora, que por esquecimento ali havia deixado, quando fora tomar banho". Jacintha escondeu o objeto da dona, que veio procurá-lo, para depois vender. Maria Vapor viu tudo e disse que o objeto estava em poder de Jacintha. 0 ódio entre ambas começou então. Pedro Ventania jurou vingar-se de Maria Vapor e do carroceiro $^{48 .}$

No dia 9 de fevereiro de 1902, quando o carroceiro retornara do trabalho, Pedro Ventania e ele iniciaram uma luta, "indo os dois até dentro da maré", que foi separada pela intervenção dos vizinhos. Mas quando estes se recolheram, os dois voltaram a brigar, dessa vez com o apoio de Maria Vapor e Maria Jacintha. Da briga, o resultado foi Pedro Ventania, auxiliado pela amásia, assassinarem José Anastácio e Maria Vapor. Maria Jacintha, pela denúncia, teria fornecido a arma do crime. A coparticipação de Maria Jacintha estaria provada ainda pelos ferimentos que ela sofrera de "Maria Vapor", e que constavam no corpo de delito ${ }^{49}$. Se eu tivesse mais elementos, até arriscaria dizer que a briga estaria relacionada com as prévias carnavalescas daquele ano. Contudo, possuo apenas o depoimento de Anna Joaquina do Espírito Santo, uma doméstica de 50 anos, mas animada o suficiente para estar "voltando" do carnaval com uma vizinha, quando "ouviram um barulho" ${ }^{\prime 50}$.

Muita gente foi acionada para elucidar o caso. O artista Augusto José de Santa-Anna, de 30 anos de idade, analfabeto, e vizinho dos envolvidos, revelou que Maria Vapor deu um compasso para José Anastácio, que estava embriagado, enquanto Pedro Ventania fazia uso de uma faca que trazia na cinta. Enquanto os dois lutavam, Maria Vapor e Maria Jacintha também lutavam. Ventania, provavelmente vindo em socorro da amásia, teria dado duas cacetadas na cabeça de Maria Vapor e outra no peito esquerdo, ocasionando sua morte. $\mathrm{O}$ artista disse ainda que Maria Vapor "contava receber metade do preço do referido objeto [o par de brincos]". O carroceiro morto seria apenas vizinho de Maria Vapor ${ }^{51}$.

Maria da Conceição, amásia de Anastácio, sem profissão declarada, não sabia muita coisa. Mas sabia a causa de tudo, que eram as famosas "rosetas" encontradas por Maria Jacintha. Ela teria acionado a polícia já no "primeiro barulho", ou seja, na primeira luta entre os homens. Por isso não viu o desfecho da luta ${ }^{52}$.

No auto de perguntas a que foi submetida, Maria Jacintha afirmou que apenas Pedro Ventania fora o autor do duplo assassinato. Assumiu que Anastácio e Pedro lutaram antes do crime e que ela própria lutara com a outra lavadeira. Mas negou o essencial: ela não entregara o punhal para seu amásio cometer o crime. O motivo da confusão era realmente o "par de rosetas de coral com pedrinhas brancas" que ela encontrara no rio Tejipió ${ }^{53}$.

\footnotetext{
${ }^{48}$ Denúncia, fl. 2v.

${ }^{49}$ Denúncia, fl. 3.

${ }^{50}$ Denúncia, fl. 34v. Digo que deviam ser as prévias, e não os festejos de carnavalescos mesmo, porque isso explicaria o fato de o carroceiro estar trabalhando.

${ }^{51}$ Denúncia, fl. 17-18.

52 Denúncia, fl. 21-23.

${ }^{53}$ Denúncia, fl. 23-25.
} 
Outro operário foi interrogado. O trabalhador da linha férrea de Caruaru, Fortunato Vicente da Silva, pernambucano, casado, de 33 anos, também morador na Ilha Fernandinho, vinha do trabalho com o carroceiro Anastácio e presenciou a primeira luta entre os dois. Interrompida a luta pela intervenção dele e dos demais vizinhos, e indo cear, ouviu os vizinhos gritarem que eles estavam de novo em luta. Saiu, ficou na porta, decidiu não intervir, julgando melhor ir ao quartel chamar a polícia, mas, a caminho, já encontrou os praças da polícia, que tinham sido acionados por Maria da Conceição. Pela primeira vez, falou-se de participação direta de Maria Jacintha no crime, que teria esfaqueado Maria vapor $^{54}$.

Menos do que um conflito entre domésticas pernambucanas, o que se tem aqui é um conflito no seio de grupos populares em situação precária, vivendo na periferia de um dos bairros centrais do Recife, e que envolve duas lavadeiras. Isso fica claro até mesmo pelo rol de testemunhas listadas no inquérito, que incluía nada menos do que doze pessoas. Destas, apenas sete testemunharam perante o juiz José Cavalcanti Paes Barreto, membro de tradicional família pernambucana. A ilha toda viu ou ouviu a cena dramática ${ }^{55}$.

No tribunal, algumas testemunhas voltaram à cena e outras novas surgiram. Nesta fase do processo, depuseram Anna Joaquina do Espírito Santo, solteira, 50 anos de idade, do "serviço doméstico", analfabeta; Jesuína Maria da Conceição, solteira, 30 anos de idade, também do "serviço doméstico", analfabeta; a seguir vieram os testemunhos do jornaleiro analfabeto, pernambucano, casado, Florentino Antonio de Oliveira; do comerciante paraibano, casado, alfabetizado, João Francisco de Mendonça; do agricultor José Joaquim de Sant'Anna, de 26 anos, pernambucano, solteiro, analfabeto; e do jornaleiro alfabetizado, pernambucano, solteiro, Sebastião José de Lima. Todos residentes em Fernandinho.

Anna Joaquina, aquela que estaria voltando do carnaval, não tinha muita coisa a dizer sobre o acontecimento. Ao ouvirem o "barulho", ela e Jesuína se recolheram. Ao sair depois, viu Maria Vapor ferida, que disse apenas que o fora por uma mulher, mas sem denunciar o nome. Seja como for, diante da morte, a doméstica foi solidária com Maria Vapor, botando um tição de fogo na mão dela para não morrer sem vela. Sua fala, contudo, não incriminava Jacintha, e mostrou mesmo desconhecer o motivo do crime ${ }^{56}$. Acredito que Anna não queria se indispor com Maria Jacintha, caso esta fosse absolvida. Mortos o carroceiro e a lavadeira Maria Vapor, a vida continuava, e era prudente não gerar mais tensão.

Já o operário da Estrada Central de Pernambuco, Fortunato, foi mais contundente ao culpar Jacintha. Foi a testemunha que mais indícios ofereceu contra a lavadeira. Declarou:

que quando chegou com a polícia ao lugar das mortes ouviu dizer que a denunciada presente não só lutara e ferira a ofendida Maria Vapor, como também fornecera ao denunciado Ventania seu amásio um punhal em que ele cometera as duas mortes, sendo certo que quando ele depoente acabou de apartar a primeira

\footnotetext{
${ }^{54}$ Denúncia, fl. 25v-27v.

${ }^{55}$ Denúncia, fl. 29.

${ }^{56}$ Denúncia, fl. 34v-35.
} 
luta havida entre o denunciado e o ofendido José Anastácio a denunciada presente estivera junto de $\operatorname{todos}^{57}$.

Mesmo assim, por ter ido chamar a polícia, ele não vira a segunda luta, que gerou as mortes. Do fato principal, portanto, ele fala de "ouvir dizer", ou seja, a fofoca dos moradores tendia a responsabilizar também Jacintha como ativa no desenrolar dos fatos.

Cúmplice com a doméstica Anna Joaquina, com quem voltara do "carnaval", a doméstica Jesuína botou toda a culpa para cima de Pedro Ventania: "quanto a denunciada presente, nada sabe", pois "não ouviu dizer nem viu a denunciada presente tomar parte na luta". Contudo, apesar da vontade em ajudar Jacintha, declarou ter ouvido dizer que esta entregara a faca com que Ventania golpeara as vítimas ${ }^{58}$. As três testemunhas acima foram ouvidas no dia 17 de março de 1902. As demais deviam ser ouvidas no dia 24, mas não compareceram. Não era incomum este "desaparecimento" de testemunhas. Muita gente evitava falar de um tema tão delicado em um tribunal, preferindo tecer seus rumores entre vizinhos mesmo, o que seria menos comprometedor para futuras alianças e solidariedades. Mas não teve jeito. No dia 8 de abril as outras quatro pessoas tiveram de comparecer. 0 jornaleiro Florentino declarou que vira, de sua casa, o carroceiro Anastácio e a lavadeira Maria Vapor chegarem à casa de Pedro Ventania "armados ambos de cacete", dando início à agressão. Isso já traz algum atenuante para Ventania e Jacintha. Sobre esta, só ficou claro para o jornaleiro que ela estava "presente no meio do povo", acompanhando o amásio e as vítimas, ignorando se ela teria dado a arma para Pedro Ventania.

O comerciante paraibano estava mais preocupado com seu jantar. Ao ouvir falar do "barulho", por volta das cinco horas da tarde, estava jantando, saiu e viu as cenas da primeira luta, mas voltou a sua casa "para concluir o jantar". Depois saiu novamente, viu Anastácio ferido e, "muito mais tarde", também Maria Vapor. Ora, esse "muito mais tarde" é importante, pois dá a entender que ele ignorava qualquer ação de Jacintha nas lutas. Ele não teria ouvido dizer que ela "tivesse tomado parte no barulho, nem fornecido arma ao denunciado Ventania". Os dois últimos depoentes também não incriminaram a lavadeira ${ }^{59}$.

Para concluir a história, as cenas de violência no meio popular inflavam domésticas e outros tipos de trabalhadores, e era um momento crucial na política cotidiana dos subordinados: era preciso escolher com quem se alinhar, a quem atingir com suas fofocas e comentários maliciosos, a quem livrar de uma punição judicial. O grupo ajustava suas tensões. Neste caso, não apenas duas domésticas foram solidárias com a lavadeira acusada, como mesmo outros trabalhadores do lugar estavam, aparentemente, querendo botar panos quentes na história. À exceção do empregado da Estrada Central de Pernambuco, os demais queriam que a vida do grupo voltasse à rotina. Teria sido uma luta entre iguais. Finalizada com as mortes de uma das partes, a outra teria de ser agregada novamente ao

\footnotetext{
${ }^{57}$ Denúncia, fl. 36-36v.

${ }^{58}$ Denúncia, fls. 37 e $37 \mathrm{v}$.

59 Denúncia, fls. $44 v$ e 45.
} 
convívio da comunidade. A solidariedade popular, e entre as próprias domésticas, é o saldo que fica de toda a história. Não estou aqui adoçando a violência crua que, de fato, existiu. Apenas não acredito que conflitos dessa natureza devam ser interpretados como signo de desagregação social, de ruptura, de anomia. Ficar nessa constatação é não historicizar o fenômeno e desprezar lógicas populares na solução de seus conflitos.

Quero entender também por que a lavadeira Maria Vapor estava tão interessada nos brincos que a outra lavadeira encontrou. Duvido muito que ela julgasse obrigação da lavadeira Jacintha devolver o objeto à verdadeira dona. Aqui valia o ditado "achado não é roubado". Ela, por ter visto a companheira encontrar o objeto, só queria dividir com ela o par de brincos. Talvez Vapor julgasse mesmo que a atitude "egoísta" da outra lavadeira fosse uma quebra das regras do grupo, e que Jacintha estaria obtendo vantagens e privilégios indevidos, porque todas as mulheres de lá eram iguais e deviam continuar sendo. O conflito, portanto, parece mesquinho, mas não é. Do ponto de vista da falecida, Fernandinho não era lugar para uma mulher se destacar com um par de brincos melhor do que o de todas as outras $^{60}$.

\section{SEIOS TÚMIDOS E DUAS PARDAS BAIANAS}

Se o leitor julgou fútil a causa deste conflito ocorrido no Recife, nem quero imaginar o que ele vai pensar desta outra história que envolveu duas baianas, uma engomadeira e a outra cozinheira, em Salvador. A história das duas me interessa porque acredito, através dela, poder compreender como se dava a solução de conflitos no meio popular, os tipos de valores que eram acionados, os motivos propriamente de gênero, entre outros temas. $O$ resumo policial do caso é este. A engomadeira Romana e a cozinheira Anna Cândida, em luta corporal, feriram-se mutuamente na noite do dia 19 de março de 1899, na roça do doutor Lobo, nos Barris. A engomadeira feriu a cozinheira com navalhadas, e a segunda usou um pau no confronto. Romana foi presa em flagrante. Não sei se ajudada por alguém, o fato é que Anna não fora presa apesar de ser também responsabilizada criminalmente. Talvez o fato de apenas Romana tentar fugir quando "perseguida pelo clamor público" tenha dado mais motivos para a prisão. Ao ver o sangue no corpo de Anna, a população se indignou ${ }^{61}$.

Mas é preciso apresentá-las melhor: Romana era filha natural de certa Cândida Francisca dos Passos, tinha 20 ou 23 anos de idade, solteira, e havia nascido na Freguesia da Vitória, na própria Salvador; Anna, por sua vez, tinha 21 anos de idade, e também só declarou o nome da mãe, que era Maria Roza. Anna também era solteira, mas não tinha nascido em Salvador. Ela era natural de Cachoeira, cidade do Recôncavo Baiano, e vivia de

\footnotetext{
${ }^{60}$ Uma interpretação parecida para fenômenos também semelhantes se encontra em CHALHOUB, Sidney. Trabalho, lar e botequim: o cotidiano dos trabalhadores no Rio de Janeiro da belle époque. 2a ed. Campinas, SP: Editora da UNICAMP, 2001, p. 184-202.

${ }^{61}$ Ver APEB, Seção Judiciária, Série Lesões Corporais. Rés: Romana Ferreira de Sant'Anna e Anna Cândida de Almeida. Estante 215, cx. 19, doc. 5, Bahia, 1899. Citado sempre Lesões Corporais, Romana, seguido da folha.
} 
"alugar-se para o serviço doméstico" como cozinheira. Romana sabia ler e escrever, Anna não. No corpo de delito, os médicos as registraram como pardas ${ }^{62}$.

As versões são conflitantes quanto aos motivos e à autoria dos primeiros golpes.

Romana declarou:

que durante o dia de hoje - desde o amanhecer - tem sido provocada por Anna Cândida de Almeida, a qual, dizendo enraivecida ter sabido que a respondente dissera - que ela não tinha casaco para vestir, servia-se de palavras imorais para insultá-la constantemente; que ela acusada, afim de evitar qualquer conflito, não respondia às suas descomposturas, até que, estando assentada na porta da casa de Martiniano de tal, às nove horas da noite, mais ou menos, por estar sem sono conforme já tinha dito à Josepha (também residente na supradita roça), por quem foi aconselhada para ir dormir, quando na porta da casa de Eloy, em frente à de Martiniano, achava-se a referida Anna de Almeida, esta - continuando no propósito de provocá-la - foi fazer-lhe uma pergunta com os mesmos termos obscenos, que tanto a ofendiam como a sua mãe - dela respondente, repetindo certas frases tão feias e injuriosas que a acusada não pôde deixar de responderIhe. ${ }^{63}$.

Seguiu-se então a troca de golpes: Anna teria, "furiosamente", dado cacetadas nela, enquanto Romana teria se defendido de sua agressora com uma navalha. Romana, como sabia escrever, assinou o auto de perguntas, às 11 horas da noite do mesmo dia 19 de março em que ocorreu a luta. Anna contou outra história:

que no dia dezenove [...], pela manhã, estando em sua casa, perto da de Romana, ouviu esta dizer que ela respondente era uma descarada, e que andava "em mangas de camisa" por não ter casaco para vestir; pelo que respondeu-lhe: Você, para poder xingar assim, deve pedir a sua mãe um casaco para me dar, que então Romana a insultou com uns nomes tão ruins, tão imorais, que ela não pode repetir; que saiu para a rua sem responder, e à tarde encontrou-se (dentro da roça) com Romana, acompanhada de outra mulher, e a mesma Romana disse-lhe que tinha precisão de conversar com ela respondente, porem "fora do portão", e portanto queria saber - se ela ainda tinha de sair à rua; que respondeu negativamente, e retirou-se - com receio de ser agredida pela dita Romana e sua companheira. [...] à noite do mesmo dia, cerca de nove horas, estava assentada na porta da casa de Eloy, quando chegou Romana e continuou a insultá-la; e que ela respondente, por saber que Romana estava armada de navalha, deu-lhe uma pancada com um pedaço de tábua, afim de desarmá-la, e nessa ocasião "foi agarrada por Aniceto" e ferida pela aludida Romana, a qual, tendo fugido pelo caminho da fonte, foi presa por Eloy Firmino Muniz, que estava dormindo à hora do conflito, e acordou ao ouvir os gritos da respondente e das outras pessoas que ali se achavam ${ }^{64}$.

\footnotetext{
${ }^{62}$ Na década de 1880, Salvador "foi o destino principal de grande número de escravos fugidos do Recôncavo", como disse Fraga. Não posso afirmar que Anna fosse alguma ingênua nascida após a Lei do Ventre Livre, mas ela faz parte deste contexto em que migrar de engenhos para cidades do Recôncavo, e destas para Salvador, era muito comum. Mulheres libertas e livres compunham este fluxo migratório. Ver FILHO, Walter Fraga. Encruzilhadas da liberdade: histórias de escravos e libertos na Bahia (1870-1910). Campinas, SP: Editora da UNICAMP, 2006, cap. 9. A citação está na p. 329.

${ }^{63}$ Lesões Corporais, Romana, fl. 6v-7.

${ }^{64}$ Lesões Corporais, Romana, fl. 8-8v. Anna respondeu ao auto de perguntas na manhã do dia seguinte, no Hospital de Santa Izabel, pertencente à Santa Casa de Misericórdia, onde estava recebendo tratamento médico.
} 
Anna negou ter alguma rixa com Romana. Há um teor moral nas duas versões. Uma não teria suportado as ofensas morais da outra. Romana admitiu que Anna tinha escutado algumas fofocas supostamente esgrimidas por ela. Anna disse mesmo à autoridade policial que Romana não suportava que ela andasse "em mangas de camisa", e que a chamava por isso de "descarada". Contudo, confesso que ainda não tinha entendido muito bem por que as duas chegaram à agressão física. Foi preciso a lavadeira Maria Damiana, de 23 anos, solteira, filha natural, nascida em Salvador, deixar tudo mais claro. Como os outros, morava na roça do doutor Lobo, nos Barris. Provavelmente lavava roupas na fonte que existia na roça, para onde Romana tentou fugir. Ela declarou que, no mesmo dia da confusão, foi interpelada por Anna para saber se ela tinha dito a Romana que ela andava sem casaco "para mostrar os peitos", ao que Damiana, talvez assustada, esquivou-se: "se disse, não se lembrava". E finalizou:

que além disso, tinha muito trabalho em que ia se ocupar, e não podia, portanto, nem queria "perder tempo com barulho e mexericos"; que depois de uma troca de descomposturas entre as ditas Romana e Anna, esta "meteu o cacete" em Romana, [...] que atracou-se com a sua agressora, e "deu-lhe alguns golpes de navalha e correu, tendo sido elas, na ocasião do conflito, apartadas por Aniceto dos Santos; que ela testemunha retirou-se para a sua casa, e soube depois terem sido presas Romana e Anna ${ }^{65}$.

Pelo visto, não era uma questão social do tipo você não tem casaco e eu tenho, mas uma questão de gênero e de honra: você não usa casaco porque é descarada e quer mostrar os peitos. Por isso Anna começou tudo. Os depoimentos das demais testemunhas evidenciaram que os primeiros golpes foram de Anna, com o cacete, e que depois Romana a cortou de navalha. A própria Anna, o leitor deve lembrar, reconheceu que deu a cacetada por saber (ou ter notado) que Romana estava armada com a navalha. Mesmo sabendo muito, a lavadeira Damiana quis mostrar-se amiga do trabalho, séria e responsável, diferente do grupo, moralizada por uma ética do trabalho que tanto agradava aos ouvidos de autoridades policiais e judiciárias. Talvez ela tivesse mesmo muitos clientes a atender, roupas a lavar e engomar.

Romana se deu pior, provavelmente, por ter atingido melhor a rival. A cacetada fez um corte no lado esquerdo de sua cabeça, mas não foi um golpe forte, já que pôde correr. Agora as várias navalhadas sofridas por Anna fizeram estrago maior, e sangue sempre causa uma impressão feia. Por isso a prisão, a fiança e, por fim, a condenação do tribunal do júri. A engomadeira teria praticado o ato criminoso por "motivo reprovado" ${ }^{66}$. Já a cozinheira Anna foi inocentada e arrematou que "o motivo da acusação era a inveja que lhe devotava Romana Ferreira de Sant'Anna por possuir ela respondente seios túmidos, qualidade esta

\footnotetext{
${ }^{65}$ Lesões Corporais, Romana, fl. 16.

${ }^{66}$ Lesões Corporais, Romana, fl. 72.
} 
que despertava a cobiça de todos que a viam" ${ }^{67}$. Mas antes de encurtar, registro que o sumário de culpa foi se arrastando tanto que a engomadeira e a cozinheira já tinham deixado de morar na roça do doutor Lobo. Pelo visto, não tinham muitos laços com o grupo. Uma se sentia cobiçada pelas mulheres do lugar, a outra não ficou bem-vista depois das navalhadas que dera. Por fim, Anna estava residindo na Rua da Cabeça, na Freguesia de São Pedro, desde março, e Romana na Rua da Lapa, desde julho de 1899. Sem relações bem constituídas no meio dos vizinhos, as duas saíram da roça. Mudaram, portanto, de rua, mas não de freguesia ${ }^{68}$.

\section{LAÇOS COMUNITÁRIOS EM BECOS ESTREITOS}

Ao contrário de Anna e Romana, cujo conflito não mobilizou tão fortemente o grupo para nenhum dos lados, outros conflitos trazem situações bem diferentes. A doméstica Alexandrina Thereza da Conceição, de 21 anos de idade e descrita como parda no exame de corpo de delito, ao ser agredida, pôde, ao menos, contar com a solidariedade das vizinhas. Alexandrina era alagoana, mas se apresentou como natural de Sergipe ${ }^{69}$; suas vizinhas Apolinária Maria da Conceição e Maria Libania Dias eram respectivamente pernambucana e baiana, e ambas engomadeiras; outra vizinha, Maria Guilhermina do Espírito Santo, era sergipana, e também engomadeira. Não sei se Alexandrina engomava também, ou se trabalhava em casa de família. O quadro aqui descrito me leva a pensar que ela também prestava serviços de engomado ocasionalmente.

A agressão sofrida pela doméstica aconteceu na tumultuada freguesia de Santana, em Salvador, na Rua do Castanheda, no dia 3 de julho de 1898. Oyoy Portugal, desaparecido na maior parte do processo, teria golpeado Alexandrina com um instrumento cortante quando ela estava penteando os cabelos na porta de sua própria casa com a ajuda da vizinha. A ação foi considerada inesperada. Alexandrina não negou que "entretivera relações" com seu agressor. Mas isso era coisa do passado. Agora ela se negava a manter relações com ele. Em um tipo de namoro que, para ela, era bastante livre; seu amante ocasional julgou ter o direito de possuí-la à força, e ela, provavelmente, estava se esquivando. Alexandrina não era prostituta: apenas tinha um namoro muito comum entre os grupos populares: iniciou uma relação sexo-afetiva e passou algum tempo nela; depois, não viu futuro no relacionamento e queria se ver livre do homem. Ora, ela, no início, talvez até almejasse ao menos o amasiamento, mas como Oyoy não decidiu dar esse passo, cansou de esperar. O problema era que ele, filho de um certo Senhor Portugal, dono de uma loja de

\footnotetext{
${ }^{67}$ Lesões Corporais, Romana, fl. 79v.

${ }^{68}$ Lesões Corporais, Romana, fls. 51 e 52.

${ }^{69}$ Pode ter havido alguma confusão: os médicos a tomaram por alagoana, como as autoridades policiais; a princípio, ela seria sergipana. Ver APEB, Seção Judiciária, Série Lesões Corporais. Estante 215, Cx. 19, doc. 3. Lesões corporais em Alexandrina Thereza da Conceição. Réu: Antonio Pereira Portugal Filho. Bahia, 1899, fls. 7 e 9. Citado sempre Lesões Corporais, seguido do nome da vítima, local e ano.
} 
charutos, continuava a querer os favores sexuais da doméstica, talvez porque a considerasse uma quase prostituta.

Apolinária, de 38 anos de idade, era a mais velha de todas, e talvez vivesse em Salvador há mais tempo do que Guilhermina e Alexandrina, que eram ainda jovens. A engomadeira, às quatro horas da tarde, estava sentada na porta de sua casa; em outra casa, a baiana Libania penteava os cabelos da amiga, quando Oyoy chegou e feriu Alexandrina. Pelo horário, vê-se que as engomadeiras tinham tempo de sobra para o descanso de fim de tarde, para a higiene pessoal, para um banho, para, enfim, preocuparem-se com a beleza depois de um dia de trabalho. Talvez até deixassem o horário mais frio da noite para cumprir as tarefas pendentes. $\mathrm{O}$ contexto da agressão é curiosíssimo: mulheres sentadas à porta de suas casas, provavelmente já debaixo de sombra, pois a rua não passava de um beco, e o homem arrogando-se no direito de lhes tirar a paz porque queria possuir a parda Alexandrina sexualmente. Na expressão polida de Apolinária, Oyoy "se dava com Alexandrina" ${ }^{70}$.

A engomadeira baiana, que penteava o cabelo de Alexandrina, sabia do envolvimento desta com Oyoy porque o via entrar na casa de Alexandrina. A rigor, não havia por que recriminar o comportamento de Alexandrina em receber em sua casa um homem. Solteira, morando independente de patrões, ela vivia sua sexualidade como queria. Suas companheiras, também solteiras, em nada a reprovavam, e estavam dispostas a punir o agressor de Alexandrina. A sergipana Guilhermina ainda estava trabalhando quando ouviu o que se passava: "estava em sua casa gomando e ouvindo uns gritos de socorro, saiu à rua e viu a Alexandrina sua vizinha, banhada em sangue tendo ainda visto Oyoy Portugal que ferira a Alexandrina segundo Ihe disseram subindo a escada do beco em que elas residem" ${ }^{71}$.

$\mathrm{Na}$ polícia, em menos de um mês, o inquérito foi "solucionado". O problema, contudo, era que ninguém encontrava Oyoy, seja por ineficiência do aparato policial, seja por cumplicidade. O Promotor teve de mandar o inquérito de volta à autoridade policial para que este buscasse saber a identidade precisa do réu. Com ironia, disse que o fato de ele saber o nome do pai e a profissão ("negociante estabelecido com loja de charutos") já era indício que facilitava e muito a identificação do acusado, até porque a própria ofendida poderia informar onde a loja se situava. O Comissário não dava muita importância aos conflitos envolvendo mulheres agredidas ${ }^{72}$. Para cumprir o que o Promotor exigiu, o Comissário intimou o soldado pernambucano Manoel Celestino de Queiroz, que acudira Alexandrina e desarmara o réu. Pelo visto, residia em Salvador desde criança, pois sabia desde menino que o nome de Oyoy era Antonio Barbosa Portugal Filho. O pai era um negociante cuja loja se situava na Rua da Alfândega, junto ao Elevador da Conceição. Logo, o pai do agressor tinha um comércio de charutos próximo do que viria mais tarde a se chamar

\footnotetext{
${ }^{70}$ Lesões Corporais em Alexandrina Thereza da Conceição, Bahia, 1899, fl. 13 e 13v-14.

${ }^{71}$ Para o depoimento de Libania e o trecho citado, ver Lesões Corporais em Alexandrina Thereza da Conceição, Bahia, 1899, fl. 13-14 e fl. 14-15.

72 Lesões Corporais em Alexandrina Thereza da Conceição, Bahia, 1899, fl. 16v-17.
} 
Elevador Lacerda, na Freguesia de Nossa Senhora da Conceição da Praia ${ }^{73}$. 0 Comissário inquiriu um empregado da Secretaria de Polícia, e este também confirmou a identidade de Oyoy $^{74}$.

Apesar do apoio recebido pelos depoentes, Alexandrina não pôde mais contar com Guilhermina para a formação de culpa. O Oficial de Justiça que procurou intimá-la não a encontrou mais por ela "não achar-se nesta capital"75. Provavelmente retornou a Sergipe. Esses trânsitos, essas migrações, não ensejavam solidariedades permanentes entre as domésticas. Era preciso ganhar a vida onde quer que fosse. Mas a pernambucana Apolinária e a baiana Libania continuaram apoiando sua companheira de ofício e vizinha. Libania era soteropolitana, nascida na Freguesia de Santana onde, pelo visto, sempre viveu. Talvez não fosse irrelevante para domésticas de outros lugares ter uma baiana junto de si para mediar a relação com a cidade. A alagoana Alexandrina tinha nela uma amiga. Mas mesmo a ajuda é ambígua. Libania, na segunda inquirição, disse não saber a razão para o crime, nem se entre ele e Alexandrina existiam "relações de intimidade". Entendo essa ignorância como uma tática de proteção da vida sexual do grupo. Alexandrina talvez não quisesse que as autoridades a tomassem por prostituta, e pode mesmo ter aconselhado a amiga a depor de modo não muito enfático sobre as relações dela com Oyoy. Libania disse conhecê-lo desde algum tempo, "observando, por diversas vezes, achar-se o mesmo em estado de embriaguez". Ela silenciou sobre a vida sexual de Oyoy e sua amiga, mas manchou a reputação do réu ${ }^{76 .}$

Apolinária viu tudo com mais clareza, e disse que sua companheira agredida "estava pacificamente sentada a porta de sua casa", quando Oyoy a ferira com três golpes ${ }^{77}$. A pernambucana contou algo mais da intimidade de Alexandrina, dizendo que o réu a procurara por duas vezes. Apolinária, portanto, respondeu que havia sim "relações de amizade" entre a alagoana e o réu. Mas não era uma declaração forte o suficiente para que as autoridades vissem Alexandrina como uma prostituta. Ao contrário de Libania, que afirmou ignorar o motivo de o réu agredir Alexandrina, a pernambucana ensaia uma interpretação: "Respondeu atribuir à circunstância de não ter querido Alexandrina dar acolhimento ao denunciado em sua casa" ${ }^{\prime 78}$. Libania já tinha dito que Oyoy chegou com "gracejos" enquanto ela estava penteando Alexandrina. Gracejos cuja intenção o leitor não ignora: passar mais uma noite com Alexandrina. A cena está montada: assédio masculino, recusa da mulher, orgulho de macho ferido, agressão, apoio das companheiras em solidariedade tanto de gênero quanto de classe. Os homens não ajudaram muito. João Câncio só apareceu depois de várias intimações e não conhecia os envolvidos; e o soldado Manoel Celestino estava destacado no centro do Estado.

\footnotetext{
${ }^{73}$ Lesões Corporais em Alexandrina Thereza da Conceição, Bahia, 1899, fl. 20-21.

${ }^{74}$ Lesões Corporais em Alexandrina Thereza da Conceição, Bahia, 1899, fl. 22.

${ }^{75}$ Lesões Corporais em Alexandrina Thereza da Conceição, Bahia, 1899, fl. 24v.

${ }^{76}$ Lesões Corporais em Alexandrina Thereza da Conceição, Bahia, 1899, fl. 29.

${ }^{77}$ Lesões Corporais em Alexandrina Thereza da Conceição, Bahia, 1899, fl. 30.

${ }^{78}$ Lesões Corporais em Alexandrina Thereza da Conceição, Bahia, 1899, fl. 30v-31.
} 
Oyoy foi condenado à prisão, mas continuou desaparecido até o crime prescrever, e só retornou para solicitar a prescrição da pena. Conseguiu o que queria. A freguesia de Santana, em Salvador, parecia agitada quanto a crimes dessa natureza. Lesões corporais e conflitos diversos tinham lugar nesta região bastante populosa da cidade. Tratava-se uma freguesia socialmente bastante diversificada.

Um caso de ofensas físicas que discuto abaixo apresenta redes sociais constituídas entre ganhadores e domésticas e entre crioulos e africanos. O inquérito não elucida, mas é provável que os envolvidos fossem, de algum modo, vinculados à escravidão; talvez fossem mesmo libertos ou constituintes de primeira de geração de livres. A cozinheira Joanna Valeria Pires, de 25 anos, solteira, analfabeta, ora descrita como crioula, ora como preta, morava na Ladeira de Santana, e era amasiada com Porcino de Tal, também descrito como "de cor preta" e "crioulo". No dia 24 de setembro de 1894, Joanna se apresentou ao Subcomissariado de Polícia do 1 을 Distrito de Santana e declarou que tinha sido agredida pelo amásio. A autoridade seguiu a praxe: os médicos verificaram o ferimento na cabeça proveniente de uma cacetada; o lugar estava com sangue coagulado, não dando para perceber a dimensão do trauma ${ }^{79}$. Joanna era filha de certa Maria Thereza, e devia ser filha natural. Ela procurou a autoridade policial na mesma noite do crime. Ela estaria simplesmente sentada na porta de casa quando Porcino feriu-a. Perguntada se havia entre ela e Porcino alguma "desarmonia", disse "Que até viviam em completa harmonia". A resposta, creio, deixou a autoridade policial perplexa. Era necessário investigar mais, e Joanna explicou que atribuiu a agressão aos "zelos de seu amásio". A cozinheira mantinha relações estreitas com as africanas Maria e Thereza.

Maria da Conceição era uma ganhadeira africana de 59 anos e muito provavelmente chegou a Salvador no período do tráfico ilegal de escravos, ainda durante a infância ou adolescência, e teria nascido em torno de 1835 . Como as demais testemunhas, morava na Ladeira de Santana; a outra africana era Theresa Damiana da Conceição, também ganhadeira. Tinha 65 anos, e seu nascimento, portanto, pode ser situado por volta de 1829 . Ambas se enquadram naquele reduzido grupo de africanos remanescentes da escravidão na Bahia, e que tanto emocionou Nina Rodrigues ${ }^{80}$. As outras testemunhas eram Maria Julia, de 33 anos, solteira, baiana, cozinheira como a própria Joanna; e Justina Maria da Piedade, de 22 anos, solteira, baiana, e ganhadeira como as africanas. As domésticas não estabeleciam exclusivamente relações com outras domésticas. Suas experiências estão inseridas mais no âmbito de uma cultura popular que lhes permite sobreviver e arranjar solidariedades, do que adstritas a certo sentido de classe. Neste caso, há mais evidências de que o gênero e a cor tenham fornecido os principais elementos da identidade do grupo que saiu em defesa de Joanna. A classe, aqui, não é o único elemento de identidade e solidariedade.

\footnotetext{
${ }^{79}$ APEB, Seção Judiciária, Série Lesões Corporais. Estante 203, Cx. 236, doc. 12, fl. 4v-5. Lesões Corporais em Joanna Valeria Pires. Réu: Porcino de Tal. Bahia, 1894. Citado sempre Lesões Corporais em Joanna Valeria Pires, seguido do lugar, ano e folha do documento.

${ }^{80}$ Ver RODRIGUES, Nina. Os africanos no Brasil. 8a ed. Brasília: Editora Universidade de Brasília, 2004, p. 121, que estimou em pouco mais de 500 o número de africanos em Salvador.
} 
O ciúme de Porcino é unanimemente apontado como a causa da agressão. Ao contrário da posição tíbia de Joana, que afirmou viver em "completa harmonia" com o amásio, as testemunhas esposavam opiniões diferentes. Maria Julia, a cozinheira a quem Joana teria recorrido "a fim de poder escapar das cacetadas que Porcino lhe atirava", afirmou "que continuamente Porcino vive em questões com Joanna, já tendo por três vezes quebrado a cabeça d'esta e sendo assim que não pode abonar a sua conduta" ${ }^{81}$. Maria Julia, como Joana, estava também sentada na porta de sua casa. É cena que se repete: após o trabalho, sair de suas estreitas moradias para "respirar a noite". A opinião da africana Maria da Conceição sobre Porcino também não era lisonjeira. Ele seria "desordeiro" e teria ferido Joanna por diversas vezes ${ }^{82}$. As amigas tomaram as dores de Joanna e foram mais incisivas em suas declarações.

A ganhadeira baiana Justina estava conversando com Joanna, sua vizinha, quando tudo se desencadeou. Todas as amigas baianas, ainda jovens, foram interrompidas em seu momento de lazer. As africanas, bem mais idosas, não compartilhavam desse momento de lazer, e estavam no interior de suas casas. Isso não as impediu de seguir o tom geral e atribuíram a Porcino péssimas qualidades: Thereza disse que conhecia Porcino, "e que sabe de ciência própria que ele tem péssima e irregular conduta" ${ }^{83}$. A solidariedade de gênero e de raça estava bem consolidada mesmo entre trabalhadoras não necessariamente domésticas. Ganhadeiras e domésticas, exercendo atividades bem diferentes na Salvador do período pós-Abolição, não pareciam tolerantes com um homem que maltratasse sua vizinha e amiga. De fato, como resultado do inquérito, Porcino foi ao menos indiciado e pronunciado.

Mais uma vez a Freguesia de Santana é o local de uma Salvador conflituosa. No mesmo ano de 1894, a cozinheira crioula Maria Celestina, que morava na Ladeira da Prata, procurou a autoridade policial por ter sido ferida por Cassiano Bibiano do Sacramento. Celestina era "de cor preta, solteira, com vinte anos de idade". O ferimento fora provocado por uma pedra que a atingiu no maxilar superior, abaixo do olho esquerdo. A jovem cozinheira conhecia Cassiano, que era pedreiro, e a quem ela considerava crioulo ${ }^{84}$.

Celestina estava passando pelo Largo do Desterro em torno de uma hora da tarde, em direção a sua casa, quando foi abordada por Cassiano. Ele pedira que ela fosse para a casa dele. Após a recusa, reagiu violentamente, insultando-a e "agarrando-a pela cintura, foi-Ihe dando diversos sopapos" ${ }^{\prime 85}$. Ela se desvencilhou do assédio de Cassiano e correu para a Ladeira do Prata, mas, perseguida, foi alvejada com a pedra. Ela negou que houvesse "rixa" ou "inimizade" entre ambos, mas afirmou que ele a teria jurado "que havia de ensinar a

\footnotetext{
${ }^{81}$ Lesões Corporais em Joanna Valeria Pires, Bahia, 1894, fl. 8v.

82 Lesões Corporais em Joanna Valeria Pires, Bahia, 1894, fl. 10.

${ }^{83}$ Lesões Corporais em Joanna Valeria Pires, Bahia, 1894, fl. 12.

${ }^{84}$ APEB, Seção Judiciária, Série Lesões Corporais. Estante 203, Cx. 236, Doc. 3. Lesões Corporais em Maria Celestina, 1894 , fls. 5v e 6. Citado a seguir Lesões Corporais em Maria Celestina, seguido do lugar, ano e folha correspondente.

${ }^{85}$ Lesões Corporais em Maria Celestina, Bahia, 1894, fl. 7v.
} 
ela"86. Isso não diz muito. O contexto diz mais. Depuseram José Porcino da Costa ${ }^{87}$, Bernardina Maria da Silva, Maria da Conceição, Constantino Amoedo e Helena Paranhos. $\mathrm{Na}$ primeira intimação, Bernardina e Helena não foram encontradas, mas sim logo depois,, não dando a entender que tivessem a intenção de se esquivar.

A freguesia de Santana tinha ainda alguns africanos que talvez trabalhassem na freguesia de Conceição da Praia ou no Pilar, nas atividades portuárias, nos chamados cantos de ganhadores. Mas havia cantos de ganhadores também na chamada Cidade Alta, embora comportando um número menor de trabalhadores ${ }^{88}$. José Porcino da Costa era um africano de 58 anos, morava no Largo do Desterro e era ganhador; Helena, com 55 anos, era africana, ganhadeira e morava no mesmo lugar, como as demais testemunhas não africanas: a doméstica baiana Maria, o negociante espanhol Constantino e a doméstica baiana Bernardina.

Maria conhecia Celestina, mas não o agressor, e não sabia nada acerca dos motivos da violência que, pelo menos, presenciou e soube relatar em conformidade com o auto de perguntas de Celestina; o negociante espanhol conhecia a "crioula" Celestina de vista talvez fosse freguesa sua - e relatou a cena em detalhes, como a perda de "bastante sangue" da vítima, mas não sabia quem era o agressor; Bernardina nem sequer conhecia Celestina, e presenciou a briga quando ia à casa do africano José, o ganhador também intimado para esclarecer o caso; os africanos Porcino e Helena souberam, pelo menos, dizer onde Cassiano morava e sua profissão ${ }^{89}$. Só disponho do inquérito, e não posso garantir que o processo teve o encaminhamento sugerido pelo comissariado. Ao menos as testemunhas foram solidárias e seus depoimentos serviram de base para que Cassiano fosse considerado culpado e pronunciado para ser julgado no tribunal do júri. Cabe finalmente registrar que Cassiano só jogou a pedra porque a cozinheira Celestina foi capaz de, em luta corporal, safar-se da primeira tentativa de agressão. Ela não estava inerte diante do macho dominador, e buscou a autoridade policial imediatamente.

\footnotetext{
${ }^{86}$ Lesões Corporais em Maria Celestina, Bahia, 1894, fl. 8.

${ }^{87}$ Espero que José Porcino da Costa não seja o mesmo Porcino de Tal que agrediu Joanna na mesma Freguesia de Santana. Mas para deixar tudo confuso, o escrivão registrou, certa vez, o nome de Porcino de Tal como Porcino da Costa. A confusão do escrivão, contudo, não me faz acreditar que fossem a mesma pessoa.

${ }^{88}$ Não posso afirmar categoricamente que José Porcino fosse um dos tantos ex-escravos de Porcina, uma famosa senhora de escravos que possuía uma banda, denominada Banda da Chapada, composta por músicos escravos. Mas ela legou o seu nome para vários ex-escravos, inclusive escravos ganhadores, e dois deles moravam no Desterro, como é o caso de José Porcino. É uma hipótese difícil de confirmar, mas não implausível. Ver REIS, João José. “De olho no canto: trabalho de rua na véspera da Abolição”, p. 199-242. In Afro-Ásia, 24 (2000), p. 229-231. Além de João José Reis, para compreender a distribuição espacial dos cantos de trabalhadores em Salvador, ver RIBEIRO DA COSTA, Ana de Lourdes. "Espaços negros: "cantos" e "lojas" em Salvador no século XIX", p. 18-34. In Caderno CRH. Suplemento, 1991.

${ }^{89}$ Ver depoimentos em Lesões Corporais em Maria Celestina, Bahia, 1894, fl. 10-16v.
} 


\section{CONCLUSÃO}

Engomadeiras, lavadeiras, cozinheiras, muitas mulheres que trabalhavam em atividades domésticas, tinham contato estreito com ganhadores e artistas, com outros trabalhadores do meio urbano. Enquanto parentes, namorados, amigos e amásios, e também como inimigos, havia intensas trocas de experiências entre os trabalhadores, com a constituição de redes sociais e espaciais que precisam ser estudadas para compreender a vida das domésticas nas décadas finais do século XIX e início do século XX.

Aquilo que une, em muitos casos, é aquilo que separa. Viver nas mesmas ruas, dividindo cômodos e ruas estreitas, compartilhando das mesmas precariedades e possibilidades, nem sempre era um elemento facilitador de coesão racial e social. Eventos fortuitos, não raro, provocavam irrupções de ódios antigos ou de desejos novos, e o equilíbrio precário do grupo se via abalado. Algumas histórias de mulheres baianas e pernambucanas, todas exercendo serviço doméstico, indicam isso. Mas indicam solidariedades também.

É importante assinalar que mulheres procedentes de diversos fluxos migratórios, muitas vezes vindas de cidades menores ou de engenhos, forjavam redes sociais com outras domésticas, com ganhadores e ganhadores, com artistas, enfim, com um conjunto amplo de trabalhadores de Recife e Salvador. Desde muito tempo, os geógrafos costumam dizer que as aglomerações urbanas, com sua espacialidade mais rígida, dificulta a recriação de espaços físicos e simbólicos por parte de migrantes ${ }^{90}$. Mas os geógrafos também aludem à possibilidade concreta de construção de redes sociais que envolvem parentesco, trabalho, conhecimento, amizade ${ }^{91}$. A história social do trabalho tem de atentar para construções de redes sociais e espaciais em cidades, bairros, comunidades, periferias. De um lugar mais sociológico e histórico, Mike Savage já sugeriu que a análise das redes espaciais pode iluminar formas de mobilização política, e que se deve atentar para a "mobilidade e a fluidez espaciais", bem como para o modo como pessoas se tornam mediadores espaciais, na medida em que agem entre as diversas escalas de espaço ${ }^{92}$.

Ora, o que as mulheres de outras regiões construíam, nos lares e becos de Recife e Salvador, não era uma cópia de seu mundo antigo. Cedo tinham de aprender, e aprendiam,

\footnotetext{
${ }^{90}$ ALMEIDA, Carlos C. "Movimentos migratórios, espaços socioculturais e processos de aculturação", p. 203212. Comunicação apresentada por ocasião do colóquio "Trabalhadores estrangeiros na Europa Ocidental", organizado pela Comission Nationale pour les Études Interethniques, Paris-Sorbonne, 5-7 de junho de 1974. Disponível em: http://analisesocial.ics.ul.pt/documentos/1223912409N4uGK4qe9Zu62XR4.pdf Acesso em: 15/2/2011.

${ }^{91}$ Ver MATOS, Ralfo; BRAGA, Fernando. "Redes sociais, redes territoriais e migrações", p. 1-21. Disponível em: http://www.abep.nepo.unicamp.br/site eventos abep/PDF/ABEP2004 113.pdf. Acesso em: 15/2/2011. Trabalho apresentado no XIV Encontro Nacional de Estudos Populacionais, ABEP, Caxambu - MG, Brasil, 2004, p. 4.

${ }^{92}$ Ver SAVAGE, Mike. "Classe e história do trabalho", pp. 25-48. In: BATALHA, Cláudio H. M.; SILVA, Fernando Teixeira; FORTES, Alexandre. Culturas de classe: identidade e diversidade na formação do operariado. Campinas, SP: Editora da UNICAMP, 2004, p. 42.
} 
como se imiscuir nos problemas e tensões cotidianos do grupo, como mecanismo de autoproteção, como reforço de alianças. Uma vez em aglomerados urbanos, o que não faltavam eram experiências a partilhar. Por isso acredito que a tímida Guiomar do início deste artigo, pouco ou nada ajeitada com o meio urbano, sem redes constituídas, é uma figura estereotipada demais, coisa de escritor. Ela é quase uma escrava boçal recém-chegada no continente americano. Não, as mulheres que discuti aqui se situam, para tomar emprestada uma metáfora usada por historiadores, "Além de senzalas e fábricas" ${ }^{93}$, construindo espacialidades e significados próprios que, não raro, escapam ao observador mais atento. Itinerários não lineares de formação de uma classe.

Recebido em 15/02/2011

Aceito para publicação em 20/02/2011

${ }^{93}$ Ver NEGRO, Antonio Luigi; GOMES, Flávio. "Além de senzalas e fábricas: uma história social do trabalho", p. 217-240. In Tempo Social, revista de Sociologia da USP, v. 18, n 1, junho de 2006. 